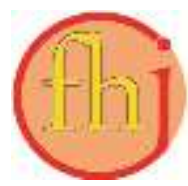

Faletehan Health Journal, 7 (3) (2020) 142-148

www. journal.Ippm-stikesfa.ac.id/ojs/index.php/FHJ

ISSN 2088-673X | e-ISSN 2597-8667

\title{
Manajemen Kemitraan dalam Peningkatan Mutu Lulusan Diploma Tiga Kebidanan
}

\author{
Nani Yunarsih ${ }^{1 *}$ \\ ${ }^{1}$ Program Studi Diploma Tiga Kebidanan, Fakultas IImu Kesehatan, Universitas Faletehan, Serang \\ *Corresponding Author: naniysudirman@gmail.com
}

\begin{abstract}
Abstrak
Meningkatnya jumlah perguruan tinggi kebidanan belum diimbangi dengan kualitas akibat minimnya sarana dan prasarana penunjang praktik klinik. Tujuan dari penelitian ini adalah untuk mengidentifikasi: 1) tujuan kemitraan, 2) program kemitraan, 3) pelaksanaan program kemitraan, 4) masalah dan tantangan yang dihadapi dalam kemitraan, 5) langkah perbaikan ke depan, dan 6) kualitas lulusan kemitraan. Objek penelitian ini adalah Akbid Aisyiah, RS Dr Drajat Prawiranegara, Akbid Bina Husada dan RS Kencana. Pengumpulan data dilakukan melalui observasi, wawancara dan studi dokumentasi. Hasil penelitian menunjukan bahwa: 1) tujuan kemitraan untuk meningkatkan mutu pendidikan dan mutu kompetensi lulusan, menjalin kemitraan jangka panjang dan melaksanakan tridarma PT, berupa kegiatan kemitraan kebidanan dan pelatihan penunjang kompetensi, 2) pelaksanaan kemitraan masih perlu perbaikan mulai dari pengorganisasian sampai ke strategi kemitraan, 3) masalah dan tantangan kemitraan dalam pengelolaan kemitraan dan pelaksanaan kepemimpinan, 4) langkah-langkah perbaikan ke depan yang meliputi pengelolaan, kegiatan, anggaran, sumber daya manusia, pihak terkait lainnya, dan kemitraan. Penelitian ini merekomendasikan dosen perlu dapat membagi waktu antara tugas akademik dengan tugas pembinaan mahasiswa dan perguruan tinggi kebidanan sebaiknya dapat merencanakan strategi operasional secara kerjasama.
\end{abstract}

Kata Kunci: Diploma Kebidanan, Kemitraan, Mutu Lulusan

\section{Partnership Management in Improving the Quality of Diploma 3 of Midwifery}

\begin{abstract}
The increasing number of midwifery colleges has not been matched with the quality due to lack of facilities and infrastructure to support clinical practices. The purpose of this study was to identify: 1) the purpose of partnership, 2) partnership program, 3) implementation of partnership program, 4) problems and challenges faced in partnership, 5) further improvement steps, and 6) qualities of partnership graduates. The object of this study were Aisyiah Midwifery Academy, Dr Drajat Prawiranegara Hospital, Bina Husada Midwifery Academy, and Kencana Hospital. Data were collected through observations, interviews and documentation study. Research results showed that: 1) the purposes of partnership in improving the quality of education and the quality of graduate competence, establishing long-term partnerships and implementing threefold missions of higher education, have the form of midwifery partnership activities and competency support training, 2) the implementation of partnership still needs improvement starting from organizing to partnership strategies, 3) partnership issues and challenges in the management and leadership implementation, 4) further improvement steps including management, activities, budget, human resources, other related parties, and partnership. This study recommended lecturers to be able to alocate their time for academic duties and student coaching duties and midwifery colleges to plan operational strategies in collaboration.

Keywords: Midwifery Diploma, Partnership, Graduate Qualities
\end{abstract}


Faletehan Health Journal, 7 (3) (2020) 142-148

\section{Pendahuluan}

Pendidikan tinggi kesehatan merupakan salah satu pendidikan tinggi yang sedang tumbuh dan berkembang di Indonesia. Salah satu pendidikan tinggi kesehatan itu adalah pendidikan tinggi Kebidanan yang dibentuk untuk menyiapkan peserta didik menjadi anggota masyarakat yang memiliki kemampuan akademik dan profesional yang dapat menerapkan, mengembangkan, dan/atau menciptakan IPTEK dibidang kebidanan. Sistem pendidikan tinggi kebidanan sebagai landasan integral dari sistem pendidikan tinggi merupakan kesatuan dari staf akademik dan peserta didik yang mempunyai kemampuan serta potensi dalam profesi, ilmiah, belajar dan kreasi yang tinggi.

Profesi kebidanan memiliki dasar pendidikan yang kuat sehingga dapat dikembangkan setinggitingginya. Hal ini menyebabkan profesi kebidanan selalu dituntut untuk mengembangkan dirinya untuk berpartisipasi aktif dalam sistem pelayanan kesehatan di Indonesia. Profesionalisme kebidanan ditujukan agar dapat memajukan pelayanan kesehatan masyarakat dibidang kebidanan. Dasar dibentuknya pendidikan kebidanan yaitu keputusan direktorat pendidikan tinggi nomor SK No. 4277/dikti/ kep/ 1999, tentang landasan dibentuknya pendidikan Kebidanan di Indonesia. Keputusan ini didasarkan karena Kebidanan mempunyai kerangka tubuh pengetahuan yang kuat dan lengkap. Selain juga mendapat rekornendasi dari organisasi profesi Bidan yaitu Ikatan Bidan Indonesia (IBI). Pengakuan kedudukan Kebidanan diperkuat lagi dengan diakuinya Bidan sebagai profesi pada UndangUndang Kesehatan No.23 Tahun 1992 serta dijabarkan keberadaan profesi Bidan sebagai satu dari enam kelompok profesi kesehatan yang ada di Indonesia pada Peraturan Pemerintah No. 32 Tahun 1996.

Pendidikan tinggi kebidanan merupakan suatu proses yang penting dilakukan secara terstruktur dan bertanggung jawab untuk menghasilkan tenaga-tenaga yang handal, kompeten, belajar terus menerus, dan mampu merespon kebutuhan rnasyarakat baik secara lokal, nasional, maupun global. Untuk itu institusi penyelenggara program pendidikan tinggi Kebidanan memerlukan keselarasan, kesinambungan, dan keteraturan dalam berbagai upaya peningkatan serta pendayagunaan berbagai sumber agar berdaya guna dan berhasil guna. Pendidikan tinggi Kebidanan diharapkan menghasilkan tenaga kebidanan profesional yang mampu mengadakan pembaruan dan perbaikan mutu pelayanan dan asuhan Kebidanan, serta penataan perkembangan kehidupan profesi kebidanan. Namun hal ini masih harus diibuktikan oleh institusi kebidanan dalam memberikan kontribusi terbaik bagi layanan Kebidanan profesional.

Kebidanan sebagai suatu profesi, dalam melaksanakan tugas dan tanggungjawab pengembanggannya harus mampu mandiri. Untuk itu diperlukan wadah yang mempunyai fungsi utama untuk menetapkan, mengatur serta mengendalikan berbagai hal yang berkaitan dengan profesi seperti pengaturan hak dan batas kewenangan, standar praktek, standar pendidikan, legislasi, kode etik profesi dan peraturan lain yang berkaitan dengan profesi kebidanan. Pendidikan tinggi Kebidanan diharapkan menghasilkan tenaga Kebidanan profesional yang mampu mengadakan pembaruan dan perbaikan mutu pelayanan atau asuhan kebidanan, serta penataan perkernbangan kehidupan profesi kebidanan secara terus menerus dan berkesinambungan.

Bidan dalam menjalankan peran dan tanggungjawabnya sanga dituntut memiliki pengetahuan, ketrampilan, dan sikap yang baik yang dapat menunjang tindak perilaku profesionalnya. Pengetahuan, ketrampilan, dan sikap yang baik akan dapat diperoleh dalam lingkungan perguruan tinggi yang memiliki komitmen yang kuat untuk mencetak Bidan yang profesional. Tentunya perlu juga ditunjang dengan lahan praktek yang memadai dan sesuai dengan standar yang telah ditetapkan. Berbagai lahan praktik yang menjadi tempat pengalaman belajar klinik dan pengalaman belajar lapangan dibina dan dikembangkan sedemikian rupa sehingga mampu memberikan pengalaman belajar nyata yang diperlukan oleh calon-calon mahasiswa kebidanan. Lahan praktik yang pada umumnya terdiri atas lebih dari satu fasilitas pelayanan Kebidanan, dikembangkan dalam satu kesatuan sebagai jaringan lahan praktik.

Mutu lulusan Bidan harus dapat diakui dan dihargai oleh tempat layanan kesehatan yang ada sehingga nantinya pelayanan kesehatan akan semakin meningkat dan professional. Harapan ini tentunya harus menjadi pekerjaan dari institusi pendidikan kebidanan karena masih ada institusi 
pendidikan Kebidanan yang belum optimal menjalankan manajemen pendidikannya. Untuk mewujudkan Kebidanan sebagai profesi yang sudah ada, beberapa syarat yang harus dipenuhi seperti mempunyai "body of knowledge" yang spesifik, memberikan pelayanan kepada masyarakat melalui praktik keprofesian yang didasari motivasi altruistik, mempunyai standar kompetensi, dan kode etik profesi. Para praktisi dipersiapkan melalui pendidikan khusus pada jenjang pendidikan tinggi.

Kurangnya lahan tempat melakukan praktik dan kerjasama institusi pelayanan kesehatan, tentu akan mempengaruhi kualitas dan kompetensi lulusan. "Selama ini rumah sakit pendidikan hanya digunakan urtuk mahasiswa kedokteran, belum.ada yang dikhususkan untuk Bidan. Hal ini menyebabkan mahasiswa ilmu Kebidanan mengalami diskriminasi, tidak boleh memegang pasien, serta harus membayar untuk kerja praktik di rumah sakit. Padahal untuk menjadi Bidan professional mutlak diperiukan kerja praktik di rumah sakit bagi sarjana/kebidanan, sebagaimana sarjana kcdokteran memerlukan kcrja praktik untuk menjadi dokter." (Tjiptoheriyanto, Priyono dan Nagib, Laila, 2008)

Melihat permasalahan di atas perlu adanya upaya penataan pengelolaan institusi pendidikan dalam upaya untuk memperbaiki dan meningkatkan pelayanan institusi kebidanan yang pada akhirnya menghasilkan mutu lulusan yang berkompetensi dan jiwa wirausaha. Salah satu bentuk penataan tersebut dapat melalui kemitraan dengan tempat layanan kesehatan. Kemitraan ini diharapkan dapat membantu permasalahan institusi Kebidanan seperti kurangnya fasilitas praktik, susahnya untuk menjalin kerjasama dalam pengelolan praktik mahasiswa, kurangnya program dan kegiatan yang dapat mendukung dan meningkatkan kompetensi Bidan dan sebagainya. Mutu pendidikan akan lahir dari system perencanaan yang baik (good planning system) dengan materi dan system dan tata kelola yang baik (good governance system) dan disampaikan oleh guru yang baik (good teachers) dengan komponen pendidikan yang bermutu khususnya guru. (Mulyasana, 2011:120)

Salah satu mutu pendidikan di pendidikan tinggi Kebidanan adalah mengenai tata kelola pendidikan khususnya pengelolaan program kemitraan dengan institusi layanan kesehatan. Pendidikan tinggi Kebidanan mustahil berjalan sendiri tanpa bantuan dari institusi layanan kesehatan, terutama dikarenakan terbatasnya sumberdaya rranusia, anggaran dan sarana prasarana. Dalam menjalankau praktik profesi Kebidanan tentu harus di tempat Rumah sakit karena dengan praktik Kebidanan akan meningkatkan kompetensi dan pengalaman karena langsung terjun praktek di tempat kerja.

Kemitraan antara perguruan tinggi dengan industri kesehatan seperti tempat layanan kesehatan akan menjadikan perguruan tinggi lebih mandiri. Apa yang disediakan perguruan tinggi pun akan menemukan titik temunya dengan kebutuhan tempat layanan kesehatan. Perguruan tinggi akan dengan leluasa mengembangkan penelitian dan pendidikan, sementara itu tempat layanan kesehatan akan memperoleh manfaat yang diperlukannya dari perguruan tinggi baik dalam bentuk hasil penelitian rnaupun penyediaan tenaga medis yang dibutuhkan.

Konsep penyelenggaraan kerjasama pendidikan antara perguruan tinggi dari industri di Indonesia dekat dengan model link and match yang digagas oleh Wardiman Djojonegoro. Menjalankan Link and Match bukanlah hal yang sederhana. Karena itu, idealnya, ada tiga komponen yang harus bergerak simultan untuk menyukseskan program Link and Match yaitu perguruan tinggi, dunia kerja (perusahaan) dan pemerintah. Dari ketiga komponen tersebut, peran perguruan tinggi merupakan keharusan dan syarat terpenting. Kreativitas dan kecerdasan pengelola perguruan tinggi menjadi faktor penentu bagi sukses tidaknya program tersebut.

Link and Match ini adalah keterkaitan antara pemasok tenaga kerja dengan penggunanya. Dengan adanya keterkaitan ini maka pendidikan sebagai pemasok tenaga kerja dapat mengadakan hubungan-hubungan dengan dunia usaha/industri. Dalam hal ini keterkaitan antara mutu lulusan Akademi Kebidanan dengan Rumah sakit sebagai penerima lulusannya. Dengan link dan match ini suatu lembaga khususnya akademi kebidanan bisa mengadakan kerja sama dengan pihak lain khususnya dengan perusahaan atau industri kesehatan seperti layanan kesehatan agar mahasiswa bisa magang, praktik kerja dan pslatihan di perusahaan tersebut.

Berdasarkan hasil wawancara pihak Akademi Kebidanan terdapat beberapa program kemitraan melalui praktek kerja Kebidanan, penelitian dan pengabdian kepada masyarakat serta beberapa 
Faletehan Health Journal, 7 (3) (2020) 142-148

www. journal.Ippm-stikesfa.ac.id/ojs/index.php/FHJ

ISSN 2088-673X | 2597-8667

bentuk pelatihan pelatihan. Semuanya merupakan bagian dari implementasi kemitraan yang berpotensi untuk meningkatkan mutu kompetnsi lulusan peserta didik/mahasiswa. Namun dalam pelaksanaannya masih terdapat banyak permasalahan dan kesenjangan dalam pelaksanaannya di lapangan. Maka kondisi membutuhkan peningkatan atau pengembangan progam kemitraan untuk dapat rnemperbaiki.

Dari uraian di atas permasalahan tentang mutu kompetensi lulusan salah satuya dipengaruhi oleh program kemitraan, namum kemitraan ini masih mempunyai permasalahan yang membuat kualitas kemitraan masih rendah. Hal ini dilakukan upaya perbaikan dengan melibatkan banyak pihak yang terkait. Tanpa adanya upaya perbaikan kualitas kemitraan maka mutu kompetensi lulusan Bidan akan mengalami hambatan bahkan akan sulit untuk mengimbangi percepatan perkembangan iptek dan bersamg dengan kemajuan indsutri kesehatan.

Berdasarkan uraian di atas penulis melaksanakan sebuah penelitian tentang " Manajemen Kemitraan Antara Akademi Kebidanan dengan Rumah Sakit dalam Peningkatan Mutu Lulusan Akademi Kebidanan dipilih tempat ini karena peminat masyarakat ke tempat ini untuk mengkuliahkan putra putrinya cukup banyak.

\section{Metode Penelitian}

Penelitian ini menggunakan pendekatan kualitatif dengan cara mengamati dan pengumpulan data yang dilaksanakan dalam latar/seting alamiah, artinya tanpa memanipulasi subjek yang diteliti (sebagaimana adanya, natur) (Moleong, 2011:60). Penelitian ini menggunakan beberapa pertimbangan sebagai berikut:

1. Peneliti berusaha memahani subyek penelitian berdasarkan ";perspektif peneliti. sebagai orang luas;

2. Bangunan pradigma ilmu pendidikn di Indonesia belum maksimal dan dasar kesejahteraan belum kokoh

3. lebih memperkaya wawasan dan pemahaman serta mendalam tentang relung-relung dunia pend dikan;

4. Pemahaman teniang realita social psikologi pendidikan dihampiri secara alamiah. apa adanya, induktif, grounde, sangat dibutuhkan untuk menyiasati berbagai masalah pendidikan;
5. Diharapkan dapat mampu menawarkan alternative alternative permasalahan yang lebih membumi dan mendasar;

6. Secara komplementer, hasil penelitian kualitatif yang dilakukan dengan benar dan tepat memberikan penjelasan mendalam terhadap hasil hasil penelitian yang diperoleh dari penelitian yang menggunakan teknik survey kuantitatif yang mengandalkan generalisasi (dalam ruang dan waktu)

Berdasar beberapa pendapat di atas, sasaran penelitian diarahkan pada usaha menguasai teoriteori penelitian bersifat deskriptif, dengan penguasaan pada proses penelitian, membatasi studi pada program studi Kebidanan dengan fokus kajian pada program kemitraan perguruan tinggi dengan dunia industri.

Subjek penelitian adalah sumber utama data penelitian, yaitu Akademi Diploma Tiga Kebidanan dengan Manajemen Rumah Sakit. Data penelitian dikumpulkan dengan cara observasi, wawancara dan dokumentasi. Wawancara dilakukan kepada informan yaitu pihak pimpinan Akademi Diploma Tiga Kebidanan dan Manajemen Rumah Sakit yang terdapat di Kabupaten Serang.

\section{Hasil dan Pembahasan Umum}

Dengan Manajemen Program kemitraan yang baik dan komprehensif dengan institusi layanan kesehatan, akan berjalan lancar serta didukung melalui kegiatan praktik kerja profesi Kebidanan dan pelatihan kompetensi. Sehingga Pelaksanaan kegiatan kemitraan akan mampu meningkatkan kompetensi dan mutu lulusan Kebidanan.

\section{Khusus}

Tujuan kemitraan Akademi Kebidanan dengan Institusi Rumah Sakit yang utama yaitu untuk meningkatkan kompetensi dan mutu lulusan serta menjalin hubungan dan jaringan kemitraan jangka panjang dengan institusi layanan kesehatan, selain itu juga untuk melaksanakan tri darma perguruan tinggi. Keterlibatan personil dan SDM dalam melakukan kegiatan yaitu ketua prodi Kebidanan, dosen dan staf sedangkan dari pihak institusi Rumah Sakit terutama para petugas medis yang ditunjuk oleh rumah sakit seperti Bidan senior atau CI (Clinical Instucture). Kemitraan dicantumkan dalam naskah MoU namun masih banyak tujuan dan bentuk kegiatan lain yang belum 
tercantum dalam naskah kemitraan. Sedangkan bentuk kemitraan yang dilaksanakan melalui praktek Kebidanan dan pelatihan pendukung kompetensi Bidan.

Program kemitraan yang baik dan komprehensif dengan institusi layanan kesehatan, akan berjalan lancar serta didukung melalui kegiatan praktik kerja profesi Kebidanan dan pelatihan kompetensi. Sehingga Pelaksanaan kegiatan kemitraan akan mampu meningkatkan kompetensi dan mutu lulusan Kebidanan. Implementasi kemitraan yang dilaksanakan masih banyak perbaikan dimulai dari pengorganisasian yang belum mencerminkan adanya manajemen pembagian tugas yang terukur, terarah dan tertib. Mekanisme kemitraan dimulai dari perencanaan, penjajagan, penandatanganan MoU, pelaksanaan, bimbingan, evaluasi dan pelaporan. Strategi kemitraan yang telah dilaksanakan melalui strategi aliansi dan strategi persahabatan. Sedangkan dalam pelaksanaannya Akbid melakukan praktek keperawtan dengan berbagai institusi Rumah Sakit yang berada di Banten, OKI Jakarta dan Jawa Barat, sedangkan Akbid banyak melakukan kemitraan dengan institusi Rumah Sakit yang ada di daerah Tangerang.

Masalah dan tantangan dalam kemitraan terdapat dalam hal manajemen pengeloaan kemitraan dan penerapan kepemimpinan yang berhubungan dengan kemitraan masih kurang seperti perencanaan belum optimal, jumlah institusi Rumah Sakit belum banyak, penataan organisasi belum baik, waktu dan jumlah dosen dalam bimbingan belum optimal. Aturan dan peratuan dalam MoU belum lengkap, harus ada peningkatan anggaran, perlu melibatkan pihak lain yang dapat membantu dan mengembangkan kemitraan, perlu adanya penambahan pelatihan lain dalam mendukung kompetensi mahasiswa.

Langkah perbaikan program latihan dengan cara mengadakan penataan manajemen dan kepemimpinan kemitraan yang dimulai dari perencanaan kemitraan yang strategis serta mencerminkan pengelolaan yang efektif dan produktif, berani melakukan penjajagan dengan institusi Rumah Sakit yang lebih maju dan besar lagi serta menambah bentuk kegiatan kemitraan. Selain itu perlu mengadakan penataan organisasi kemitraan sehingga dapat mengatasi masalah waktu dan pola bimbingan dosen dan CI, mempersiapkan pembekalan yang matang bagi mahasiswa untuk lebih memahami tugas dan tanggung jawa serta etika selama proses pembelajaran. Dalam naskah perjanjian kemitraan/kerjasama dibuat lebih lengkap mencakup hal kegiatan-kegiatan yang menunjang mutu dan kompetensi mahasiswa, kewajiban dan hak masing masing pihak lebih detil serta menambah kegiatan program kemitraan. Mengupayakan peningkatan sumber anggaran untuk menambah biaya biaya pelaksanaan program kemitraan dan tidak mengurangi mutu dan hasil yang diinginkan bahkan diupayakan lebih meningkat lagi, serta penggunaan anggaran lebih efektif dan selektif.

Langkah perbaikan lainnya yaitu dengan mengadakan penambahan personil dan SDM melalui pola rekruitmen atau kerjasama dengan prodi atau Akbid lain supaya tidak mengganggu pelaksanaan kegiatan kemitraan. Mutu lulusan dalam program kemitraan antara Perguruan Tinggi D3 Kebidanan dengan Rumah Sakit dalam meningkatkan mutu lulusan baik dalam hal hardskills maupun softskill. Hardskills merupakan penguasaan ilmu pengetahuan, teknologi, dan keterampilan teknis yang berhubungan dengan bidang ilmunya. Sementara itu, softskills adalah keterampilan seseorang dalam berhubungan dengan orang lain (interpersonal skills) dan keterampilan dalam mengatur dirinya sendiri (intrapersonal skills) yang mampu mengembangkan unjuk kerja secara maksimal diantaranya adalah integritas, inisiatif, motivasi, etika, kerja sama dalam tim, kepemimpinan, kemauan belajar, komitmen, mendengarkan, tangguh, fleksibel, komunikasi lisan, jujur, berargumen logis, dan lainnya. Keterampilanketerampilan tersebut umumnya berkembang dalam kehidupan bermasyarakat. Atribut softskills ini dimiliki oleh setiap orang dengan kadar yang berbeda-beda, dipengaruhi oleh kebiasaan berfikir, berkata, bertindak dan bersikap. Namun, atribut ini dapat berubah jika yang bersangkutan mau merubahnya dengan cara berlatih membiasakan diri dengan hal-hal yang baru.setelah Mahasiswa mendapatkan pengetahuan, Keterampilan dari dosennya berkaitan dengan kompetensi yang di capai, maka dengan sendirinya lulusan dapat berkualitas dengan baik, sehingga Akbid sudah banyak mendapatkan hasil lulusannya memiliki kompetensi sehingga mudah di serap oleh dunia kerja. 
Faletehan Health Journal, 7 (3) (2020) 142-148

www. journal.Ippm-stikesfa.ac.id/ojs/index.php/FHJ

ISSN 2088-673X | 2597-8667

Implikasi

Program kemitraan yang baik dan komprehensif dengan institusi layanan kesehatan, akan berjalan lancar serta didukung melalui kegiatan praktik kerja profesi Kebidanan dan pelatihan kompetensi. Sehingga Pelaksanaan kegiatan kemitraan akan mampu meningkatkan kompetensi dan mutu lulusan Kebidanan. Implementasi kemitraan yang dilaksanakan masih banyak perbaikan dimulai dari pengorganisasian yang belum mencerminkan adanya manajemen pembagian tugas yang terukur, terarah dan tertib. Mekanisme kemitraan dimulai dari perencanaan, penjajagan, penandatanganan MoU, pelaksanaan, bimbingan, evaluasi dan pelaporan. Strategi kemitraan yang telah dilaksanakan melalui strategi aliansi dan strategi persahabatan. Sedangkan dalam pelaksanaannya Akbid melakukan praktek keperawtan dengan berbagai institusi Rumah Sakit yang berada di Banten, OKI Jakarta dan Jawa Barat. Program kemitraan Akbid dengan institusi Rumah Sakit lebih banyak dilakukan pada Rumah Sakit yang terdapat di wilayah Tangerang.

Masalah dan tantangan dalam kemitraan terdapat dalam hal manajemen pengeloaan kemitraan dan penerapan kepemimpinan yang berhubungan dengan kemitraan masih kurang. Kekurangan tersebut diantaranya adalah perencanaan yang belum optimal, jumlah institusi Rumah Sakit belum banyak, penataan organisasi belum baik, waktu dan jumlah dosen dalam bimbingan belum optimal. Aturan dan peratuan dalam MoU belum lengkap, harus ada peningkatan anggaran, perlu melibatkan pihak lain yang dapat membantu dan mengembangkan kemitraan, perlu adanya penambahan pelatihan lain dalam mendukung kompetensi mahasiswa.

Untuk langkah solusi perbaikan ke depan dilakukan dengan upaya sebagai berikut:

1. Mengadakan penataan manajemen dan kepemimpinan kemitraan dimulai dari perencanaan kemitraan yang strategi mencerminkan pengelolaan yang efektif dan produktif, berani melakukan penjajagan dengan institusi Rumah Sakityang lebih maju dan besar lagi serta menambah bentuk kegiatan kemitraan, mengadakan penataan organisasi kemitraan sehingga dapat mengatasi masalah waktu dan pola bimbingan dosen dan CI, serta persiapan dan pembekalan bagi mahasiswa untuk lebih memahami tugas dan tanggung jawa serta etika.
2. Dalam naskah perjanjian kemitraan/kerjasama dibuat lebih lengkap mencakup hal kegiatankegiatan yang menunjang mutu dan kompetensi mahasiswa, kewajiban dan hak masing masing pihak lebih detil dan jelas lagi serta menambah kegiatan program kemitraan.

3. Mengupayakan peningkatan sumber anggaran untuk menambah biaya biaya pelaksanaan program kemitraan dan tidak mengurangi mutu dan hasil yang diinginkan bahkan diupayakan lebih meningkat lagi, serta penggunaan anggaran lebih efektif dan selektif.

4. Mengadakan penambahan personil dan SDM melalui pola rektemen atau kerjasama dengan prodi atau akbid lain supaya tidak mengganggu pelaksanaan kegiatan kemitraan.

5. Mutu lulusan dalam program kemitraan antara perguruan tinggi Diploma Tiga kebidanan dengan rumah sakit dalam meningkatkan mutu lulusan harus mencakup hardskills dan softskills.

\section{Simpulan}

Untuk pimpinan perguruan tinggi perlu membangun kemitraan sebagai upaya peningkatan mutu pendidikan dibidang penelitian, pengabdian masyarakat, penyaluran lulusan, kegiatan pengembangan SDM dan kegiatan pengembanan kurikulum lainnya. Perguruan tinggi perlu untuk mengembangkan badan otonom seperti LPPM yang bertanggung jawab terhadap program kemitraan dengan institusi Rumah Sakit. Perguruan Tinggi perlu membuat perencanaan strategis kerjasama dengan institusi Rumah Sakit dan industri kesehatan supaya menciptkan link and mach dalam pembelajaran dan selalu mengikuti perkembangan ilmu dan teknologi kesehatan dan Kebidanan khususnya.

\section{Referensi}

Akdon, (2011) Strategic Manajement For Educational Manajement (Manajemen Strategik untuk Manajemen Pendidikan. Penerbit Alfabeta Bandung.

Bendriyanti, (2014) Manajemen Mutu Lay-anan Akademik Dalam Meningkatkan Kompetensi Lulusan Pergnntan Tinggi

Fstlah, N,(2004)Landasan Manajemen Pendidikan, Bandung, Reroaja Rosda Karya,

Hcndarman, (2012) Kebijakan Pendidikan di Indonesia. Penerbit Jcnggala Pustaka Utama Surabaya. 
Kinchelo, Joe L (2014) Guru Sehagai Peneliti, Pemberdayaan Mutu Guru Dngan Metode Panduan Penelitian Kualitatif. Penerbit IRCiSoD Yogyakarta.

Kasali, Rhenald (2007) Manajemen Perubahan dan Manajemen Harapan Penerbit PT Gramedia Pusiaka Utama Jakarta

Mulyadi, (2014) Sistem Terpadu Pengelolaan Kinerja Personel Berbasis Balance Scorcard. Penerbit UPP-STIM YKPN Yogyakarta.

Moleong, Lexy J (2012) Metodologi Penelitian Kualitatif. Penerbit PT Remaja Rosdakarya Bandung.

Rangkuti, Freddy, (2015) SWOT Balance Scorecard. Penerbit PT Gramedia Pustaka Utama Jakarta

Raehmat, (2014) Manajemen Strategik. Penerbit CV. Pustaka Setia Bandung.

Sukmadinata, Nana Syaodih (2011) Metode Penelitian Pendidikan. Penerbit PT Remaja Rosdakarya Bandung,

Sugiyonp, (2015) Metode Penelitian Pendidikan, Pendekatan Kuantatif, kuaUtatif, dan $R \& D$, Penerbit Alfabeta Bandung

Sugiyono, (2013) Metode Penelitian Kombinasi (Mixed Methods) Penerbit Alfabeta Bandung

Sanusi, Achmad (2014) Pembaharuan Strategi Pendidikan. Penerbit Nuansa Cendekia Bandung.

Soyomukti, Nurani (2015) Teori-teori Pendidikan. Penerbit Ar-Ruzz Media Yogyakarta
Tjipptono, Fandy dan Anastasia Diana (2014), Total Quality Manajement. Penebit Andi Offset Yogyakarta.

Yuliantoro, Agus. (2015) Penelitian Tindakan Kelas dengan Metode Mutakhir untuk Pengembangan Profesi Guru. Penerbit ANDI Yogyakarta.

Zahroh, Aminatul (2014), Total Quality Management (Teori dan Praktik Manajemen Untuk Mendongkrak Mutu Pendfdtkan). Peneifeit Ar-Ruzz Media Yogyakarta

Mohammad Nabilels 2009. Informasi Pendidikan Kebidanan di Indonesia. In the http://vyww.lrc-kmpk.ugm.ac.id (http://kusdiantimelani.blogspot.com) diakses pada tanggal 1 September 2017

Syaifoel. Hardy, Kualitas Nursing di Indonesia : $\quad$ Penggerogotan Sistematis Profesi, http://www.inna-ppni.or.id diakses 5 September 2017 http://www.aipni-ainec.com Kepmendiknas No. 232/U/2000 Peraturan Presiden Nomor 8 Tahun 2012 UU No. 13/2003 tentang Ketenagakerjaan

Peraturan Pemerintah Nomor 19 Tahun 2005 Tentang Standar Nasional Pendidikan (SNP)

Peraturan Menteri Kesehatan Republik Indonesia No.340/MENKES/PER/III/2010

Keputusan Menteri Kesehatan Republik Indonesia No.1210/Menkes/SK/X/2010 